\title{
SEMIOTIKA KOMUNIKASI VISUAL: SISTEM PEMAKNAAN IKLAN ROKOK U MILD VERSI SEPANJANG JALAN KENANGAN
}

\author{
Winata Faturahman \\ Program Studi Ilmu Komunikasi Universitas Serang Raya \\ Email: gofatur@yahoo.com
}

\begin{abstract}
Advertisement is a mass media that serves to offer and promote products. Ads must have a massage that consumers can understand so they can know the product. Visual is on medium to communicate the ads massage and more effective than ads by voice. Visual communication makes a product can reach a wider consumer because consumrs can see the product offered. $U$ mild is a cigarette product in Indonesia. $U$ mild effort to reach consumers to present ads on television. Semiotic is a science that is closely related to the communication of an advertisement. In semiotic there is a meaning system that can be used to examine the communication of an advertisement massage. The meaning system can discribe the visual communication dilivered an advertisement, in this case is how the meaning system of $U$ mild cigarette advertisement "Sepanjang Jalan Kenangan" version.
\end{abstract}

Keywords: Advrtisement, Visual Communication, Semiotic, Meaning System

\section{PENDAHULUAN}

Televisi merupakan salah satu media massa yang sampai saat ini masih bertahan sebagai media massa elektronik yang digunakan masyarakat untuk memperoleh informasi dari berbagai daerah. Kehadiran televisi mempermudah masyarakat untuk mengakses berbagai bentuk informasi mulai dari berita, musik, gaya hidup, dan lain-lain. Menurut Kamus Besar Bahasa Indonesia televisi adalah sistem penyiaran gambar yang disertai dengan bunyi (suara) melalui kabel atau melalui angkasa dengan menggunakan alat yang mengubah cahaya (gambar) dan bunyi (suara) menjadi gelombang listrik dan mengubahnya kembali menjadi berkas cahaya yang dapat dilihat dan bunyi yang dapat didengar.

Penjelasan tentang pengertian televisi tersebut bisa kita uraikan bahwa televisi merupakan salah satu media elektronik yang terdiri dari gambar dan suara sehingga informasi yang disampaikan bisa dilihat dan didengarkan oleh penontonnya. Informasiinformasi tersebut dikemas oleh stasiun televisi dalam bentuk program acara televisi yang setiap waktu dapat dinikmati oleh para pemirsanya. Setiap program televisi mempunyai rating yang nantinya rating tersebut akan menunjukkan apakah sebuah program televisi dapat diterima masyarakat atau tidak. Program televisi yang mempunyai rating tinggi tentunya merupakan program yang disukai/ banyak ditonton masyarakat pada umumnya, begitu juga sebaliknya. Berbicara tentang stasiun televisi tentunya tidak lepas dari income/pemasukan yang didapat oleh stasiun televisi tersebut. Income dari stasiun televisi bisa diperoleh dari berbagai sumber seperti sponsorship dan iklan yang ditayangkan di sebuah stasiun televisi tersebut.

Iklan adalah sarana untuk mempromosikan, menawarkan, dan memperkenalkan sebuah produk baik dalam bentuk barang ataupun jasa kepada masyarakat dengan tujuan produk yang ditawarkan akan dibeli oleh konsumen.

Pengertian iklan menurut Rhenald Kasali dalam jurnal UltimArt Vol. III (2011:65): Pesan yang menawarkan suatu produk yang ditujukan kepada masyarakat lewat suatu media. Hal tersebut diperkuat oleh Hasan Shadaly yang mengemukakan:"Iklan 
adalah suatu bentuk pemberitahuan penawaran barang-barang atau jasa kepada khalayak ramai dengan tujuan, secara langsung atau tidak langsung, membantu menawarkan barang dagangan, mencari pekerjaan dan tenaga kerja atau sebagainya."

Merujuk pada uraian tentang pengertian iklan tersebut dapat ditarik sebuah kesimpulan bahwa di dalam iklan terdapat informasi, penawaran, dan pesan. Informasi di dalam iklan terdapat pada penjelasan tentang produk yang ditawarkan, sedang penawarannya ada pada produk yang ditawarkan. Pesan dari iklan tersebut terdapat pada bentuk iklan baik melalui gambar atau tulisan yang mendukung produk tersebut.

Perkembangan teknologi yang berkembang pesat menjadi hal yang berdampak positif bagi dunia periklanan. Produsen produk menawarkan produk melalui iklan di televisi dengan berbagai variasi dalam menawarkan produknya. Rokok sebagai barang yang disebut penyumbang cukai terbesar di Indonesia tidak ketinggalan dalam menawarkan produknya melalui ikla di televisi. Keterbatasan dengan adanya aturan bahwa iklan rokok tidak diperbolehkan memvisualkan bentuk rokoknya tidak menjadi halangan untuk berkreatifitas dalam membuat sebuah iklan rokok. Imej digunakan sebagai sesuatu hal yang mewakili karakter dari sebuah rokok. Imej ini divisualkan melalui adegan dalam iklan yang sudah dirancang oleh para pembuat iklan yang nantinya dapat ditonton oleh masyarakat. Hal ini membentuk sebuah proses komunikasi tidak langsung antara iklan tersebut dengan penonton.

Secara terminologis, komunikasi berarti proses penyampaian suatu pernyataan oleh seseorang kepada orang lain. Sedangkan menurut Karlfried Knapp, komunikasi merupakan interaksi antarpribadi yang menggunakan simbol linguistik, seperti sistem simbol verbal (kata-kata) dan nonverbal. Sistem ini dapat disosialisasikan secara langsung/tatap muka atau melalui media lainnya (tulisan, oral, dan visual).
Adanya aturan tentang iklan rokok yang tidak memperbolehkan memvisualkan secara verbal produk tersebut menjadikan iklan rokok mempunyai visual yang kuat dalam menyampaikan produknya.

U Mild adalah salah satu contoh produk rokok di Indonesia yang mempunyai imej anak muda. Hal tersebut dapat dilihat dari iklan-iklan $U$ mild yang menampilkan visualkan dengan pemeran anak-anak muda. Imej ini dibentuk sebagai pesan bahwa $U$ Mild ada untuk para anak muda. Iklan terbaru Umild memvisualkan bagaimana anak-anak muda dengan aktivitas bersama komunitasnya. Ada hal yang paradoks dari iklan terbaru U Mild yaitu penggunaan lagu kenangan berjudul Sepanjang Jalan Kenangan dengan imej U Mild yang muda. Hal tersebut tentunya menarik untuk dikaji tentang semiotika komunikasi visual dari iklan U Mild terbaru tersebut.

Dari uraian di atas bisa ditarik rumusan masalah, bagaimana sistem pemaknaan iklan U Mild versi Sepanjang Jalan Kenangan sehingga informasi dan pesan dapat dengan baik diterima oleh penonton?

\section{METODE PENELITIAN}

Subjek penelitian adalah iklan televisi dari Rokok U-Mild. Untuk keperluan penelitian tidak semua versi iklan rokok UMild dijadikan sebagai subjek, tetapi hanya satu versi saja. Sumber data dari penelitian adalah video iklan rokok U-Mild versi Sepanjang Jalan Kenangan. Teknik pengumpulan data dilakukan dengan mengambil video dari website yang bisa dipertanggungjawabkan keabsahannya. Data yang telah masuk kemudian dianalisis dengan metode kualitatif dengan langkah-langkah reduksi data, display data, dan penarikan kesimpulan. 


\section{HASIL DAN PEMBAHASAN}

\section{Iklan}

Marcel Danesi dalam bukunya Pengantar Memahami Semiotika Media (2002:222) menyatakan tentang iklan:

Iklan telah menjadi salah satu komunikasi massa yang paling mudah dikenal dan menarik perhatian dengan hampir seluruh anggota masyarakat terpapar padanya. Citra dan pesan yang setiap hari disebarkan oleh iklan menggambarkan pemandangan sosial kontemporer.

Pada penjelasan tersebut dapat dijabarkan bahwa dalam iklan terdapat komunikasi antara komunikator dengan komunikan yang dapat menarik perhatian melalui citra dan pesan yang ada pada iklan. Melalui visual dari iklan masyarakat dapat mengetahui produk yang ditawarkan oleh produsen, bhakan iklan juga dapat menjadi faktor laku atau tidaknya sebuah produk.

\section{Iklan Televisi}

Kehadiran televisi memberi pengaruh yang besar terhadap dunia periklanan. Iklan media cetak dan offset dianggap tidak efektif untuk penawaran secara luas. Mulai dari saat itu orang-orang beralih beriklan melalui televisi. Televisi mempunyai jangkauan yang lebih luas sehingga dianggap efektif menarik konsumen dan produk atau jasa yang ditawarkan lebih jelas karena menggunakan gambar bergerak dan audio.

Perkembangan iklan televisi mengalami kemajuan yang cukup pesat. diawali pada tahun 1947 dimana iklan televisi merupakan iklan sponsorship yang memperbaiki keterbatasan iklan radio dan iklan di media cetak. Jangkauan iklan televisi yang lebih luas dan dengan tampilan visual yang lebih hidup menjadikan iklan televisi menjadi sebuah alternatif iklan yang mulai digunakan. Hal tersebut terbukti di tahun 1948 stasiun televisi CBS mulai menayangkan iklan televisi sponsorship untuk sebuah program acara. Kemajuan pesat iklan televisi terus terjadi pada tahun 1960, 1977, 1984, dan sampai sekarang.

\section{Komunikasi Iklan Televisi}

Ditinjau dari perspektif komunikasi, Liliweri (dalam Sumartono, 2002:13) menyatakan bahwa iklan dianggap sebagai teknik penyampaian pesan yang efektif dalam penjualan produk. Oleh karena itu, dalah aktivitas perpindahan informasi tentang suatu produk yang diiklankan kepada khalayak tentunya harus mengandung daya tarik sehingga mampu mengunggah perasaan khalayak.

Iklan televisi yang sekarang ini banyak dijumpai memberikan efek besar bagi masyarakat yaitu masyarakat dapat lebih selektif dalam memilih produk tertentu melalui komunikasi yang terjadi antara komunikator (iklan tersebut) dan komunikan (penonton). Informasi yang ada pada iklan televisi menjadi sebuah komunikasi satu arah yang dapat diterima dengan baik oleh masyarakat melalui gambar bergeraknya dibandingkan dengan iklan media cetak yang terbatas dalam visualisasinya karena hanya sebuah gambar diam.

Berbicara tentang komunikasi iklan, maka tidak lepas dari semiotika. menurut Barthes dalam Sobur (2003:15) semiotika adalah ilmu atau metode analisis untuk mengkaji tanda. Hal tersebut dapat diuraikan bahwa semiotika pada dasarnya mempelajari bagaimana memaknai berbagai hal. Memaknai diartikan bahwa objek-objek tidak hanya membawa informasi, dalam hal mana objek tersebut berkomunikasi, tetapi juga mengkonstitusi sistem terstruktur dari tanda.

Pada iklan televisi terdapat semiotika yang berkomunikasi melalui visual yang ditampilkan dengan tanda-tanda yang sudah terstruktur. Hal tersebut dikenal dengan Semiotika Komunikasi Visual. Menurut Sumbo Tinarbuko Semiotika Komunikasi Visual merupakan sebuah upaya memberikan intepretasi terhadap keilmuan semiotika itu sendiri. Semiotika KOmunikasi Visual mengkaji tanda dalam konteks komunikasi 
yang lebih luas, yang melibatkan berbagai elemen komunikasi.

\section{Semiotika Komunikasi Visual Iklan U Mild versi Sepanjang Jalan Kenangan}

Iklan terbaru rokok U Mild menampilkan visual tentang para pria muda yang berada diantara masing-masing komunitasnya. Mereka melakukan aktivitas sesuai masing-masing komunitasnya. Ada beberapa komunitas yang ditampilkan pada iklan versi Sepanjang Jalan Kengan tersebut diantaranya komunitas panjat tebing, komunitas berburu, komunitas motor, dan komunitas musik. Pada iklan tersebut divisualkan bagaimana mereka menikmati hobi bersama-sama dalam keadaan apapun dengan backsound tembang kenangan berjudul Sepanjang Jalan Kenangan. Adeganadegan dalam iklan televisi tersebut dapat diuraikan menjadi Semiotika Komunikasi Visual sebagai berikut:

\section{a) Sistem Pemaknaan Tingkat Pertama (Denotatif)}

Menurut Sobur, denotasi biasanya dimengerti sebagai makna harfiah, makna yang "sesungguhnya". Proses signifikasi yang secara tradisional disebut sebagai denotasi ini biasanya mengacu pada penggunaan bahasa dengan arti yang sesuai dengan apa yang terucap. Pada iklan U Mild versi Sepanjang Jalan Kenangan talent/pemeran menyanyikan sebuah lagu yang berjudul Sepanjang Jalan Kenangan secara bergantian dengan lirik yang saling berkesinambungan. Hal ini dapat diartikan bahwa lagu yang mereka nyanyikan menunjukkan keadaan yang sedang mereka lakukan.

Pada adegan pembuka pemeran komunitas panjat tebing menyanyikan lirik yang berbunyi: "sepanjang jalan kenangan,kita slalu bergandeng tangan...". Visualisasi dari lirik lagu tersebut adalah seorang pemanjat yang memegang erat tangan temannya yang akan jatuh. Pemaknaan tingkat pertama (denotatif) dapat kita lihat dari visual dengan lirik lagu yang dinyanyikan, yaitu poin kata-kata bergandengan tangan dengan visual seorang pemanjat yang memegang tangan temannya ketika akan jatuh.

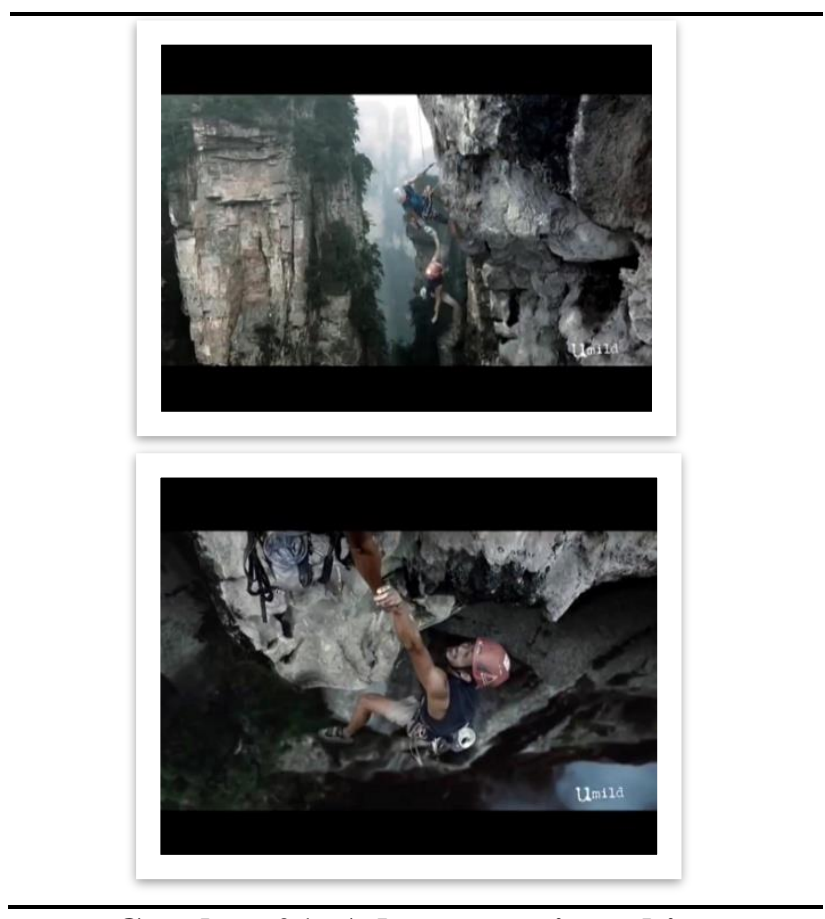

\section{Gambar 01. Adegan panjat tebing}

Scene selanjutnya adalah adegan komunitas berburu yang sedang melakukan perburuan di hutan. Adegan dibuka dengan visual dari sebuah hutan dengan adegan selanjutnya kelompok berburu muncul dari semak-semak sambil menyanyikan lanjutan lirik dari lagu Sepanjang Jalan Kenangan: "sepanjang jalan kenangan, kau peluk diriku mesra...". Adegan tersebut merupakan pemaknaan denotatif dimana lirik yang sedang dinyanyikan menggambarkan visual yang sedang ditampilkan dalam iklan. 

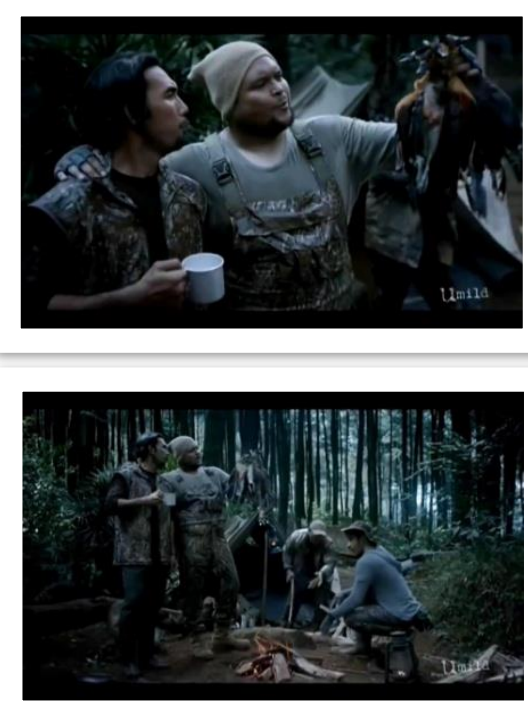

Gambar 02. Adegan berburu

Lirik yang selanjutnya dinyanyikan adalah "hujan yang rintik-rintik, di awal bulan itu..." dengan visual komunitas motor yang sedang berada di jalan raya saat hujan turun. Pemeran dari iklan tersebut menyanyikan lirik tersebut diikuti dengan adegan menaiki motor dalam kondisi hujan. Pemaknaan denotatif terdapat pada visualisasi dari lirik tersebut dengan adegan yang diperankan oleh pemeran dalam hal ini komunitas motor yang sedang mengendarai motor dalam kondisi hujan.

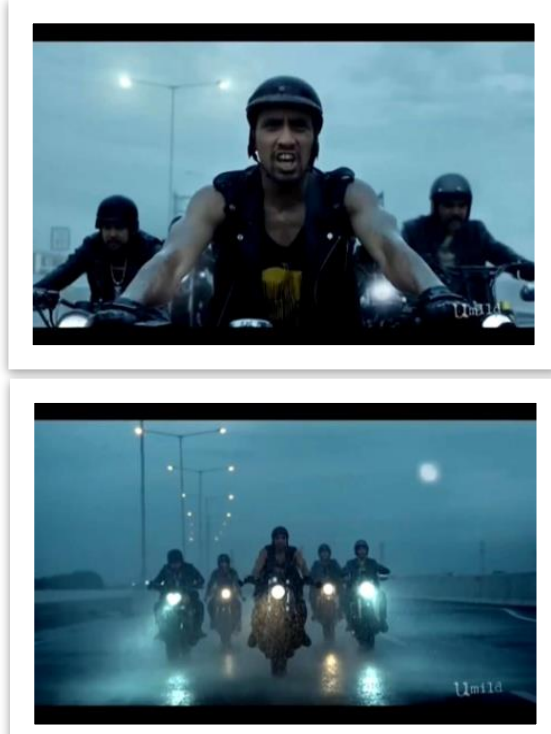

Gambar 03. Adegan komunitas motor
Adegan selanjutnya menampilkan sebuah konser musik dengan band yang sedang tampil dan ditonton penggemar band tersebut. Band tersebut menyanyikan lagu yang liriknya merupakan sambungan dari adegan sebelumnya yaitu "menambah nikmatnya malam syahdu...". Apabila dilihat dari visual dan lirik yang dinyanyikan, pemaknaan denotatif terdapat pada setting waktu ketika band tampil pada malam hari dengan lirik yang dinyanyikan ada kata-kata "malam".

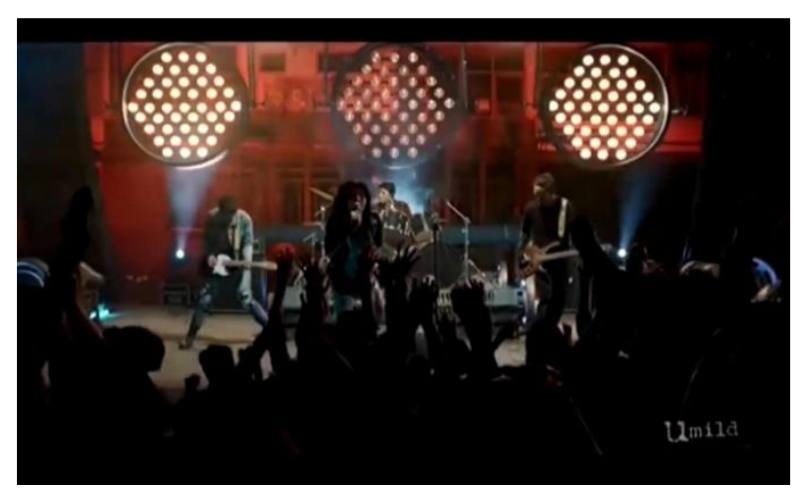

Gambar 04. Adegan Konser Band

\section{b) Sistem Pemaknaan Tingkat Kedua (Konotatif) \\ Alex Sobur menyatakan}

(Sobur,2004:69): Salah satu area penting yang dirambah Barthes dalam studinya tentang tanda adalah peran pembaca (the reader). Konotasi walaupun merupakan sifat asli tanda, membutuhkan keaktifan pembaca agar dapat berfungsi. Barthes secara panjang lebar mengulas apa yang sering disebut sebagai sistem pemaknaan tataran kedua, yang dibangun di atas sistem lain yang telah ada sebelumnya. Sistem kedua ini oleh Barthes disebut dengan konotatif, yang di dalam Mythologies secara tegas ia bedakan dari denotatif atau sistem pemaknaan tataran pertama.

Merujuk dari paparan tersebut, konotasi bisa dikatakan sebagai sistem pemaknaan yang mengalami sebuah pergeseran makna dari satu makna ke makna yang lainnya. Pada iklan U Mild versi Sepanjang Jalan Kenangan bisa diuraikan 
makna konotatifnya dilihat dari visual iklan tersebut. Pada iklan tersebut terdapat adegan dimana para anggota komunitas berkumpul dalam satu frame. Adegan tersebut merupakan adegan terakhir dalam iklan dengan memunculkan sebuah tagline "Bersaudara Itu Soal Rasa". Hal tersebut mengandung sebuah makna konotasi bahwa persaudaraan itu adalah sebuah rasa yang padu, bisa dirasakan dan dinikmati bersamasama apapun keadaannya. Ketika semua bisa merasakan rasa yang sama maka hal tersebut yang disebut persaudaraan.

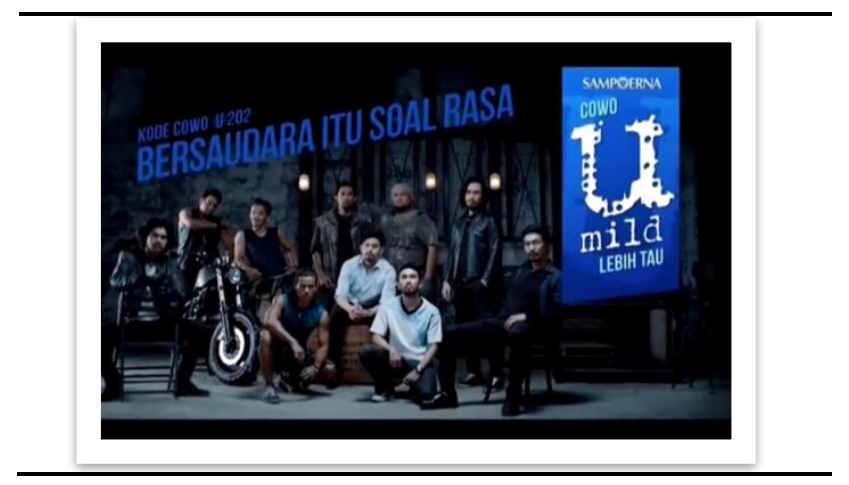

Gambar 04. Tagline U Mild

Sistem pemaknaan konotasi yang lainnya bisa dilihat dari setiap adegan pada masing-masing scene dalam iklan. Tagline yang ditampilkan dalam iklan memiliki pesan yang kuat pada setiap scenenya. U Mild menggambarkan kebersamaan dengan berbagai komunitas yang sedang melakukan aktifitas hobinya. Rasa yang sama yaitu kebersamaan dalam keadaan apapun divisualkan dengan masing-masng komunitas yang menyanyikan sebuah lagu secara bergantian tetapi berurutan, menjadikan rasa dari kebersamaan tersebut dapat dirasakan oleh semua komunitas terebut.

\section{KESIMPULAN}

Iklan merupakan media massa yang digunakan untuk memasarkan suatu produk kepada konsumen. Komunikasi visual pada iklan harus kuat agar konsumen tertarik melalui visual yang dihadirkan oleh sebuah iklan. U Mild merupakan sebuah brand rokok yang dikenal oleh masyarakat Indonesia. Upaya U Mild untuk menjaring konsumennya adalah dengan menawarkan produknya melalui iklan televisi. Salah satu iklan terbaru U Mild ada versi Sepanjang Jalan Kenangan yang menampilkan sekelompok orang di komunitasnya masing-masing. Komunitaskomunitas tersebut menyanyikan lagu berjudul Sepanjang Jalan Kenangan secara bergantian dan berkesinambungan mengucapkan lirik lagu tersebut.

Apabila dilihat dari ilmu semiotika, iklan tersebut ingin mengkomunikasikan sebuah pesan melalui visual yang ditampilkan. Komunikasi pesan tersebut bisa diuraikan dengan sistem pemaknaan yang terdapat pada setiap scene dari iklan tersebut. Sistem pemaknaan denotatif bisa dilihat dari aktivitas komunitas tersebut yang sinkron dengan lirik lagu yang mereka nyanyikan. Pemaknaan konotatif dalam iklan tersebut terdapat pada tagline U Mild "bersaudara itu soal rasa" dimana U Mild mengkonotasikan persaudaraan adalah sebuah rasa yang padu dan dapat dirasakan bersama-sama.

U Mild berupaya untuk menghadirkan kesan bahwa produk mereka adalah produk yang bisa dinikmati oleh semua kalangan dan komunitas apapun keadaannya. Narasi berbunyi "Cowok U Mild Lebih Tahu" dihadirkan untuk menekankan bahwa penikmat $U$ Mild yang tahu bagaimana bersaudara sebenarnya. Imej inilah yang dibangun U Mild untuk mengkomunikasikan pesan kepada konsumennya.

Merujuk dari pernyataan tersebut di atas maka dapat ditarik kesimpulan dalam iklan tersebut terdapat sistem pemaknaan yang dapat mengkomunikasikan pesan kepada penonton dan konsumen tentang imej produk yang dalam hal ini adalah rokok $U$ Mild. komunikasi visual yang kuat melalui pemaknaan bisa menjadikan produk tersebut menjadi produk yang mudah dikenali oleh konsumen tanpa harus memberikan informasi secara detail melalui text.

Pemaknaan secara visual juga bisa digunakan untuk menunjukan imej dari sebuah produk tanpa harus menjelaskan detail bagian dari produk. Mengingat iklan produk 
rokok tidak diperbolehkan secara vulgar menampilkan visual asli dari produk rokok. $U$ Mild memanfaatkan visual sebagai media untuk menjelaskan tentang produknya melalui komunikasi visualnya yang dalam hal ini bisa diuraikan dengan sistem pemaknaan.

\section{DAFTAR PUSTAKA}

Danesi, Marcel. 2002. Pengantar Memahami Semiotika Media. Yogyakarta: Jalasutra.

Sobur, Alex. 2013. Semiotika Komunikasi. Bandung: Remaja Rosdakarya.

Sumartono. Terperangkap Dalam Iklan: Meneropong Imbas Pesan Iklan Televisi. 2002. Bandung: Alfabeta

Tinarbuko, Sumbo. Semiotika Komunikasi Visual. Jalasutra: Yogyakarta

Ultimart: Jurnal Ilmu dan Desain Vol. III. 2011. Tangerang: Universitas Multimedia Nusantara

\section{Sumber Audio Visual:}

https://youtube.com/watch?v=DOMQM9_Fw f18 (diakses tanggal 30 Maret 2017, 12:33 WIB) 
Jurnal LONTAR Vol 5 No 1 Januari-Juni 2017, 33-40 